Headquarters: 1 rue de Varembé, Case postale 56, CH-1211

Geneva 20, Switzerland.

Website: http://www.iso.org

email: central@iso.org

Secretary-General: Alan Bryden.

\section{International Organization of the Francophonie}

The International Organization of the Francophonie represents 68 countries and provinces/regions (including 13 with observer status) using French as an official language. Objectives include the promotion of peace, democracy, and economic and social development, through political and technical co-operation. The Secretary-General is based in Paris.

Members. Albania, Andorra, Belgium, Benin, Bulgaria, Burkina Faso, Burundi, Cambodia, Cameroon, Canada, Canada-New Brunswick, Canada-Quebec, Cape Verde, Central African Republic, Chad, Comoros, Republic of the Congo, Democratic Republic of the Congo, Côte d'Ivoire, Djibouti, Dominica, Egypt, Equatorial Guinea, France, French Community of Belgium, Gabon, Greece, Guinea, Guinea-Bissau, Haiti, Laos, Lebanon, Luxembourg, Macedonia, Madagascar, Mali, Mauritania, Mauritius, Moldova, Monaco, Morocco, Niger, Romania, Rwanda, St Lucia, São Tomé e Príncipe, Senegal, Seychelles, Switzerland, Togo, Tunisia, Vanuatu, Vietnam. Associate Members. Cyprus, Ghana. Observers. Armenia, Austria, Croatia, Czech Republic, Georgia, Hungary, Lithuania, Mozambique, Poland, Serbia, Slovakia, Slovenia, Ukraine.

Headquarters: 28 rue de Bourgogne, 75007 Paris, France. Website: http://www.francophonie.org (French only)

Secretary-General: Abdou Diouf (Senegal).

\section{International Road Federation (IRF)}

The IRF is a non-profit, non-political service organization whose purpose is to encourage better road and transportation systems worldwide and to help apply technology and management practices to give maximum economic and social returns from national road investments.

Founded following the Second World War, over the years the IRF has led major global road infrastructure developments, including achieving $1,000 \mathrm{~km}$ of new roads in Mexico in the 1950s, and promoting the Pan-American Highway linking North and South America. It publishes World Road Statistics, as well as road research studies, including a 140-country inventory of road and transport research in co-operation with the US Bureau of Public Roads.

Headquarters: 2 chemin de Blandonnet, CH-1214 Vernier/GE, Switzerland.

Website: http://www.irfnet.org

Director-General (Brussels): Christophe Nicodème (Belgium).

Director-General (Geneva): Sibylle Rupprecht (Switzerland).

Director-General (Washington, D.C.): C. Patrick Sankey

(USA).

\section{International Seabed Authority (ISA)}

The ISA is an autonomous international organization established under the UN Convention on the Law of the Sea (UNCLOS) of 1982 and the 1994 Agreement relating to the implementation of Part XI of the UNCLOS. It came into existence on 16 Nov. 1994 and became fully operational in June 1996.

The administrative expenses are met from assessed contributions from its members. Membership numbered 155 in Feb. 2008; the budget for the biennium 2007-08 is US $\$ 11,782,400$.

The UNCLOS covers almost all ocean space and its uses: navigation and overflight, resource exploration and exploitation, conservation and pollution, fishing and shipping. It entitles coastal states and inhabitable islands to proclaim a 12 -mile territorial sea, a contiguous zone, a 200-mile exclusive economic zone and an extended continental shelf (in some cases). Its 320 Articles and nine Annexes constitute a guide for behaviour by states in the world's oceans, defining maritime zones, laying down rules for drawing sea boundaries, assigning legal rights, duties and responsibilities to States, and providing machinery for the settlement of disputes.

Organization. The Assembly, consisting of representatives from all member states, is the supreme organ. The 36-member Council, elected by the Assembly, includes the four largest importers or consumers of seabed minerals, four largest investors in seabed minerals, four major exporters of the same, six developing countries representing special interests and 18 members from all the geographical regions. The Council is the executive organ of the Authority. There are also two subsidiary bodies: the Legal and Technical Commission (currently 25 experts) and the Finance Committee (currently 15 experts). The Secretariat serves all the bodies of the Authority and under the 1994 Agreement is performing functions of the Enterprise (until such time as it starts to operate independently of the Secretariat). The Enterprise is the organ through which the ISA carries out deep seabed activities directly or through joint ventures.

Activities. In July 2000 the ISA adopted the Regulations for Prospecting and Exploration for Polymetallic Nodules in the Area. Pursuant thereto, it signed exploration contracts with eight contractors who have submitted plans of work for deep seabed exploration. These are: Institut Français de Recherche pour l'Exploitation de la Mer (IFREMER) and Association Française pour l'Etude de la Recherche des Nodules (AFERNOD), France; Deep Ocean Resources Development Co. Ltd (DORD), Japan; State Enterprise Yuzhmorgeologiya, Russian Federation; China Ocean Minerals Research and Development Association (COMRA); Interoceanmetal Joint Organization (IOM), a consortium sponsored by Bulgaria, Cuba, Czech Republic, Poland, Russia and Slovakia; the government of the Republic of Korea; the Republic of India; and the Federal Institute for Geosciences and Natural Resources, Germany.

Between 1998 and 2007 the ISA organized nine workshops on a range of topics, including: the development of guidelines for the assessment of the possible environmental impacts arising from exploration for polymetallic nodules; a standardized system of data interpretation; and prospects for international collaboration in marine environmental research. While continuing to develop a database on polymetallic nodules (POLYDAT), the Authority has also made significant progress towards the establishment of a central data repository for all marine minerals in the deep seabed.

Headquarters: 14-20 Port Royal St., Kingston, Jamaica.

Website: http://www.isa.org.jm

Secretary-General: Satya N. Nandan (Fiji Islands). 